\title{
PUBLIC INTEREST AND PUBLIC OVERSIGHT OF AUDITING - BULGARIAN EXPERIENCE
}

\author{
Hristo R. Mavrudiev \\ University of National and World Economy, 8-mi Dekemvri, Sofia, Bulgaria
}

\begin{abstract}
:
The paper deals with the issue of protecting public interest in the activities of the public oversight board concerning the implementation of quality control of the auditors' work. The accounting profession has changed considerably in the new millennium, in particular in the domain of audit, which will severely affect its overall position.

With more than 150 years of independent development, the audit profession has become one of the most respected and prestigious professions in the society. With the adoption of the Sarbanes-Oxley Act by the American Parliament at the beginning of the millennium, its self-development was put to an end. During this period, supervisory bodies were formed in the countries with market relations, including the entire European Union. After proper development and spacious debate between the Member States on the present cooperation of the competent supervisory bodies within the EU, the European Group of Auditors' Oversight Bodies (EGAOB) was formed. During this period, the worldwide organization of audit profession oversight was also established - International Forum of Independent Audit Regulators (IFIAR).
\end{abstract}

\author{
Key words: \\ accounting, \\ profession, \\ control, \\ audit.
}

\section{INTRODUCTION}

In the development of the accounting profession and in particular in the field of audit, substantial and significant changes occurred with the advent of the new millennium that have played a role in its overall existence and will continue to do so for many years ahead.

At the end of the past millennium, the accounting profession and in particular the audit, were solving various problems in the current operating order, as if they did not know what significant and radical changes lay ahead. One of the problems, which the profession worked on and which subsequently proved to be a storm in a teacup, was the "year 2000 problem". We all remember how many discussions, debates, publications, conferences and other activities took place regarding this issue. And as if nothing suggested the upcoming radical changes in the auditing profession, although in some countries some signs and indications could be observed.

With the raging economic scandals in the strongest economy in the world at the beginning of the millennium and the disappearance of one of the leading audit companies in the world things changed radically. Nobody expected that in the development of the socio-economic processes such changes will occur that will lead to a change in the terms and condi- countries, the public in general asked for changes which radically altered the appearance of the audit profession. The beginning of a direction in the development of the audit profession was set, which in one way or another was ignored. Until now, the audit profession has been developing independently and has built such a reputation in the society that its opinion and competence were hardly ever questioned. This was the fruit of hard and responsible work of individual professionals and of whole audit firms in the countries with a developed market economy. With more than 150 years of individual development, the auditing profession has become one of the most respected and prestigious in the society.

\section{RESULTS AND DISCUSSION}

With the adoption of the Sarbanes-Oxley Act by the American Parliament at the beginning of the millennium, an end was put to this self-development of auditing profession. Initially timidly, and subsequently in a more targeted and aggressive manner a number of developed countries took steps in this direction. Naturally, this was also done within the European Union. Initially, this was accomplished through the softer mechanism of the Union, namely by means of directives, while currently the uncompromising and mandatory procedure of the regulations is already in use. 
Thus, the society in the countries with developed market relations has imposed external oversight over the audit profession in the implementation of its activities. In the first decade of the new millennium, the overall concept for the supervision of audit profession was formed and developed. During this period, and at the moment, certain extremes in the behaviour and expressed opinions regarding the audit profession were observed. All this has led to a very lively and definitely rational discussion, both in the society and in the circles of the profession in terms of its future and its prospects for development.

During this period, supervisory organs were built mainly in the countries with market relations, including the entire European Union. A worldwide organization of the supervisory authorities over the auditing profession - International Forum of Independent Audit Regulators (IFIAR), was established and began its operations. Within the European Union, actions to coordinate and unify the activities of supervisors were also taken. After proper development, a wide debate was organized between Member States concerning the present cooperation between the competent supervisory authorities within the Union at the Committee of European Auditing Oversight Bodies (CEAOB).

With development of this entire process, society showed clearly and unambiguously to the audit profession that it highly appreciates its activities and will assist in its establishment in the socio-economic relations in market economies, but this should be done under its supervision. Thus, the audit profession, in my opinion, finally and irrevocably has lost its autonomy. And if before one of the most highlighted and underlined merits of the audit profession was its independence and self-regulation, this is no longer the case. The positive development aim of this entire process is that society did not impose complete and total control over the audit profession. Of course, in the normal market society this cannot and should not happen. In judging that supervision is a fully sufficient measure on the audit profession, society shows the existence of trust and recognizes the existence of high professional competence in this guild.

From this point of view, the overall activity of public oversight of the audit profession should be considered and developed. In this way, the public shows that it is interested in finding out and being informed about the current issues, when audits are carried out by auditors, without expressing interest in the overall work and life of the audit profession. The supervisory authority on audit should focus its efforts and activities namely in directions that protect the public interest and nothing more. This is not a quick and an easy process, but it is of the utmost importance for its implementation not to take hasty, incompetent and professionally unjustified actions that do not protect the public interest and are prompted by personal or narrow group interests.

Thus, the public has set out the technology of formation and scope of activities that should be carried out by the oversight body, using its management mechanisms. The main rule and requirement for the formation of the supervisory body is that it should be public. It is this presumption that is the basis of the activities of the supervisory authority and it is a guarantee for the protection of the public interest in its activities. This naturally means that this body should not and must not be perceived as part of the state and carry out its activities as such. The state should be an equal participant in the composition of the supervisory authority, together with all other members of civil society.

The guarantee of the public nature of the supervisory authority is the technology of its establishment and the principles on which it is to operate its activities. The supervisory authority should be established by law, as in our country, and not like in other countries, including a number of European Union Member States. The law should define the participants in the supervisory authority, including the State and other representatives of civil society. It should also state the principles based on which the activities of the supervisory authority should be carried out.

Governing members of the supervisory body should be persons who do not exercise the auditing profession, but must have professional competence in the field of auditing. Their choice should be organized in a procedure that ensures transparency and the participation of all stakeholders. In this process, the state should participate equally together with the other agents of civil society. This is the main guarantee for the social character of the supervisory authority and protection of the public interest in the supervision of the audit.

A supervisory authority formed in this way should bear certain specific responsibilities before the whole society. These responsibilities are the following

- Approval and registration of auditors;

- Adoption of documents ensuring compliance with professional ethics and quality control in the work of auditors;

- Maintaining the qualification level of the auditors;

- System of control and sanctions of auditors;

Upon formation of the supervisory authority and in carrying out of its activities, the absence of conflict of interests should be guaranteed, on the one hand between its members and the other, between them and practitioners. The supervisory authority may transfer some of its actions and responsibilities to other bodies or organizations, but subject to the requirement of absence of conflict of interest.

Investigations are one of the main functions of the supervisory authority and that must have the appropriate rights to do so. This mechanism would ensure quick and timely action in protecting the public interest by the supervisory authority.

While ensuring public interest, the supervisory authority should operate transparently by publishing annual programs and reports. To ensure the public interest, the supervisory authority must be financed adequately and transparently, in which case there should be no possibility of any undue influence by auditors.

Public interest protection in the activities of the public oversight body is connected primarily and principally to the auditors' activity. This is because the law entrusts the auditors with the task of carrying out statutory audits of certain enterprises named by the legislature, including enterprises of public interest. This means that the auditors have been assigned by society an activity that has wide public interest. Many stakeholder groups, including the state, investors and others rely on the professional and responsible work of auditors. The quality work of auditors has a direct impact on financial markets and the entire economic life of the country.

The work of auditors is of specific importance for enterprises of public interest. Due to the specifics and peculiarities of individual countries, these companies cover different groups and categories. Considering their importance throughout the European Union, the European Parliament has defined 
groups of enterprises that must be included in this category in any particular Member State, while leaving every Member State the ability, at its discretion, to include further enterprises in this category. In this situation, the protection of the public interest by supervisors in different Member States will have a different dimension.

Of particular interest in the work of the supervisory authority for the protection of the public interest is the technology of choice in terms of concrete objects - statutory auditors, to check the quality of their work. This question is interesting and covers many aspects of the work of supervisors, but it is not an object of study in this paper. The technology of choice in terms of concrete objects - statutory auditors, to check the quality of their work, is of particular importance for the work of the supervisory authority for public interest protection. This approach has its peculiarities and specifics in its application to the audit work. In this regard, , the overall activity of the supervisory authority is of particular interest for the public interest protection and quality control of audit work systemic risk in the audit profession and society as a whole. In general, systemic risk arises as a problem for the audit and its supervision with the implementation of changes in audit and audit work at the beginning of the millennium.

When organizing and realizing their activities, supervisory authorities should respect common rules and principles to ensure the general public interest within the European Union. For this reason, supervisory authorities within the European Union are obliged to organize their cooperation in terms of reviews of quality assurance and assistance in investigations of the activities of public interest entities.

The concrete organization of cooperation between supervisory authorities, not only within the European Union, should be based on the common principles adopted by the International Forum of Independent Audit Regulators (IFIAR). These basic principles have been adopted in order to promote the effectiveness of supervisory activities worldwide, as well as their independence, thereby contributing to the priority objective of the members of IFIAR - to serve the public interest by protecting investors through improving the quality of audit work.
In addition, these principles are intended for:

- Assisting members in the elaboration and development of the national legislation in specific countries using the experience of other members;

- Proactive implementation of the quality of supervisory activities in order to promote quality audit to enhance public confidence in financial statements;

- Supporting cooperation between supervisory authorities worldwide.

These principles are grouped in three main areas:

- Structure;

- Activity;

- Principles for inspections.

\section{SUMMARY}

Protection of the public interest in the activities of the public oversight body is the cornerstone in their activities. If the public oversight carries out its activities based on the above-given principles, all prerequisites required to ensure public interest will exist.

\section{REFERENCES}

ICPA. (2013). Guide to International Standards on Quality Control, Auditing, Review, Other Commitments Assurance and Related Services. Retrieved from http://www.icpainc.org

IFAC. (2012). Handbook of International Quality Control, Auditing Review, Other Assurance, and Related Services Pronouncement: Volume I. Retrieved from https://www.ifac. org/publications-resources/2012-handbook-internationalquality-control-auditing-review-other-assurance-a

EUR-Lex. (2014). Directive 2014/56/EU of the European Parliament and of the Council. Retrieved from http://eur-lex. europa.eu/legal-content/EN/TXT/?uri=celex:32014L0056

EUR-Lex. (2006). Directive 2006/43/EC of the European Parliament and of the Council. Retrieved from http://eur-lex.europa.eu/legal-content/EN/ALL/?uri=CELEX:32006L0043

The International Forum of Independent Audit Regulators - IFIAR. (2015). About Us. Retrieved from https://www.ifiar. org/About-Us.aspx/

\section{JAVNI INTERES I JAVNI NADZOR REVIZIJE NA PRIMERU BUGARSKE}

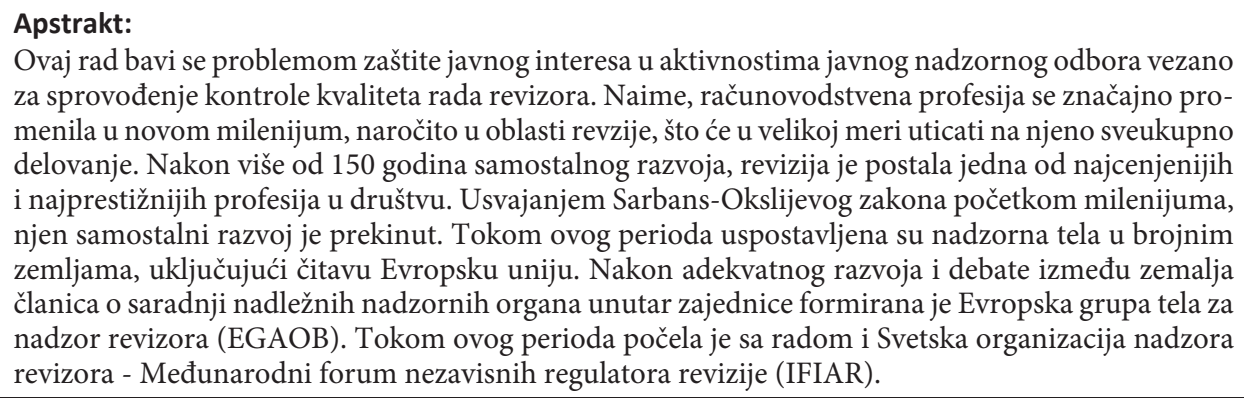

Ovaj rad bavi se problemom zaštite javnog interesa u aktivnostima javnog nadzornog odbora vezano za sprovođenje kontrole kvaliteta rada revizora. Naime, računovodstvena profesija se značajno promenila u novom milenijum, naročito u oblasti revzije, što će u velikoj meri uticati na njeno sveukupno delovanje. Nakon više od 150 godina samostalnog razvoja, revizija je postala jedna od najcenjenijih i najprestižnijih profesija u društvu. Usvajanjem Sarbans-Okslijevog zakona početkom milenijuma, njen samostalni razvoj je prekinut. Tokom ovog perioda uspostavljena su nadzorna tela u brojnim zemljama, uključujući čitavu Evropsku uniju. Nakon adekvatnog razvoja i debate između zemalja članica o saradnji nadležnih nadzornih organa unutar zajednice formirana je Evropska grupa tela za nadzor revizora (EGAOB). Tokom ovog perioda počela je sa radom i Svetska organizacija nadzora revizora - Međunarodni forum nezavisnih regulatora revizije (IFIAR).

\section{Ključne reči:}

računovodstvo,

profesija,

kontrola,

revizija. 